\title{
The genus Arctorthezia Cockerell (Hemiptera, Ortheziidae) with the description of a new species
}

\author{
Éva Szita', Mehmet Bora Kaydan ',2, Zsuzsanna Konczné Benedicty', \\ Hirotaka Tanaka ${ }^{3}$, Kinga Fetykó', Ferenc Kozár'
}

I Plant Protection Institute, Centre for Agricultural Research, Hungarian Academy of Sciences H-1022, Herman Ottó ùt 15, Budapest, Hungary 2 Çukurova Üniversity, Imamoglu Vocational School, Adana, Turkey 3 Tottori Prefectural Museum, Higashi-machi 2-124, Tottori-shi, Tottori-pref., 680-0011 Japan

Corresponding author: Éva Szita (szita.eva@agrar.mta.hu)

Academic editor:R. Blackman | Received 11 November 2014 | Accepted 10 December 2014 | Published 19 January 2015

http://zoobank.org/4937B4D3-312E-4DA6-9EFA-5122DF4EE285

Citation: SzitaÉ, Kaydan MB, Konczné Benedicty Z, Tanaka H, Fetykó K, Kozár F (2015) The genus Arctorthezia Cockerell (Hemiptera, Ortheziidae) with the description of a new species. ZooKeys 472: 59-75. doi: 10.3897/zookeys.472.8928

\begin{abstract}
This paper describes a new species of Arctorthezia Cockerell (Hemiptera: Coccoidea: Ortheziidae) from the Palaearctic region. The specimens were extracted from forest litter in the collections of Muséum d'histoire Naturelle de Genève, Switzerland, using Berlese funnels. Three further species, A. cataphracta (Olafsen), A. occidentalis (Douglas) and A. pseudoccidentalis Morrison, are redescribed and re-illustrated. The genus Arctorthezia now contains five species. An identification key, diagnostic illustrations, photographs of unmounted females and new locality records of the Arctorthezia species currently known are provided.
\end{abstract}

\section{Keywords}

Ensign scale, archaeococcoids, taxonomy, distribution, Palaearctic Region, Switzerland

\section{Introduction}

Ensign scale insects (Hemiptera: Coccoidea: Ortheziidae) are considered to be one of the most ancient families of the Coccoidea (Koteja 1996, Vea and Grimaldi 2012) and are thought to be either 'ancestral' to all scale insects or a 'primitive', isolated branch of the grade of families, the archaeococcoids (Vea and Grimaldi 2012). Ensign scales are readily distinguished by (i) possessing distinctive, well-developed legs and antennae,

Copyright Éva Szita et al. This is an open access article distributed under the terms of the Creative Commons Attribution License (CC BY 4.0), which permits unrestricted use, distribution, and reproduction in any medium, provided the original author and source are credited. 
(ii) having much of the body cloaked in bunches of white wax secretions (Vea and Grimaldi 2012). There are approximately 212 described species of Ortheziidae to date, classified in 21 genera (including four extinct genera) (Vea and Grimaldi 2012). Only a few species of ortheziids are serious pests; these include Insignorthezia insignis (Browne), the greenhouse ensign scale, and an invasive pest in Afro-tropical region, Praelongorthezia praelonga (Douglas), the citrus orthezia (Kondo et al. 2013). In Ortheziidae, two main groups of host plant specialization can be observed; the first group is composed of species that occur in leaf litter (feeding on roots and fungal mycelia), and on mosses and lichens; the second group feeds on vascular plants, including grasses, herbaceous and woody plants (Koteja 1996, Kozár 2004, Vea and Grimaldi 2012).

The subfamily Ortheziinae is characterized by having the tibia and tarsus well separated, and 7- or 8-segmented antennae (Kozár 2004). Two tribes can be recognized in the subfamily, namely Arctortheziini Kozár and Ortheziini Amyot \& Serville. The Arctortheziini includes species living in moist habitats - in litter, moss and feeding on the roots of different plants; whereas the Ortheziini includes species feeding on different kinds of plants (grasses, herbaceous, woody plants), mostly living in dry habitats. The monotypic tribe Arctortheziini includes only one genus, Arctorthezia Cockerell, which contains four living species: A. cataphracta (Olafsen), A. occidentalis (Douglas), A. pseudoccidentalis Morrison and A. vardziae Hadzibejli (Richard 1998) and one extinct species (Koteja and Zak-Ogaza 1988). Arctorthezia is characterized by (i) 9 pairs of dorsal wax plates in each marginal row, 8 pairs in the submedian band and 3 triangular or shield-shaped plates in the center of the thorax; (ii) 7- or 8-segmented antennae; (iii) 7 or 8 pairs of abdominal spiracles, and (iv) 3 or 4 spine rows within the ovisac band.

In the present paper, one new Arctorthezia species is described from the Palaearctic region (Switzerland); three species, namely A. cataphracta (Olafsen), A. occidentalis (Douglas), $A$. pseudoccidentalis Morrison, are redescribed and re-illustrated; an identification key and new additional locality records for the currently known Arctorthezia species are provided; and macromorphological characters are illustrated and discussed.

\section{Material and methods}

The specimens examined in this study were mostly from the scale insect collections of the Plant Protection Institute, Centre for Agricultural Research, Hungarian Academy of Sciences (PPI) and the Muséum d'histoire Naturelle de Genève (MHNG). Important material was processed from the Soil Zoology Collection of the Hungarian Natural History Museum, Budapest (HNMH), and part of the material was loaned from the United States National Entomological Collection, Washington (USNM). The material examined from Japan belongs to the collection of Tottori Prefectural Museum, Japan (TRPM).

Specimens were prepared for light microscopy using the slide-mounting method described by Kosztarab and Kozár (1988). The morphological terminology used follows Kozár (2004). 
The holotype of the new species is deposited in the Muséum d'histoire Naturelle de Genève collection (MHNG), and the paratypes are shared between MHNG and PPI.

The digital images of unmounted females were made with a Canon Eos400D camera and an MBC-10 stereomicroscope, and focus-stacking was processed by CombineZP software (Hadley 2010).

Measurements and counts were taken from all available material, and the values are given as a range for each character.

\section{Result and discussion}

\section{Genus Arctorthezia Cockerell, 1902}

Orthezia (Arctorthezia) Cockerell 1902: 114.

Type species: Orthezia occidentalis Douglas, 1891. Arctorthezia, Morrison 1925: 143 (as subgenus). Change of status. Arctorthezia, Morrison 1952: 53 (as genus). Change of status.

Type species. Orthezia occidentalis Douglas, 1891: 245. Subsequently designated by Cockerell 1902: 259.

Comments. Cockerell (1902) described Arctorthezia as a "section" of Orthezia. According to the International Code of Zoological Nomenclature, Article 10 (e) a "section" is deemed to be a subgeneric name when proposed for a species-group division of a genus. Thus, Cockerell is considered to be the author of Arctorthezia (Kozár 2004).

Description. Unmounted female. Live adult female with 9 pairs dorsal wax plates in each marginal row, 8 pairs in each submedian band, and 3 triangular or shieldshaped plates in centre of thorax. Ovisac parallel sided, short, about half length of body (Fig. 5).

Mounted female. Antenna 7 or 8 segmented, covered with strong spines; apical seta a blunted strong spine. Claw without denticle. Abdominal spiracles numbering 7 or 8 pairs, situated on margin of dorsum. Three triangular wax plates present on middorsum. Three or four rows of spines present within ovisac band.

Host plant. Found under mosses and stones on the roots of different plants, also reported from ant nests.

Distribution. The known species are distributed only in the Holarctic Region.

\section{Key to adult females of species of Arctorthezia}

Unfortunately the type material of $A$. vardziae was not available. For this reason we could not include this species in the key. In the original description, Hadzibejli (1963) only provided generic characters that refer to the genus description, so further studies are needed to clarify the species concept of $A$. vardziae. 
1 Triangular wax plate on mid-dorsum longer than wide; triangular wax plate between mid coxae on venter longer than wide, like those on dorsum; ovisac band containing 3 wide wax plate bands....

- Triangular wax plate on mid-dorsum various widths but never the longer than wide; triangular wax plate between mid-coxae on venter at least twice as wide as long; ovisac band containing 4 wide wax plate bands.

2
On the dorsum, with 9 circular discoidal pore plates present between marginal and submedian setal plates (Fig. 4).

A. pseudoccidentalis

- $\quad$ On the dorsum, circular discoidal pore plates absent from between marginal and submedian setal plates. ..3 Dorsal triangle-shaped mid-thoracic setal plates more than two times wider than long (Fig. 6e); distal to vulva, proportion of simple pores to quadrilocular pores ca. 1:6. A. occidentalis

- $\quad$ Dorsal triangle-shaped mid-thoracic setal plates hardly wider than long (Fig. $6 a)$; distal to vulva, proportion of simple pores to quadrilocular pores ca. $1: 15$

A. helvetica sp. n.

\section{Arctorthezia helvetica Kozár \& Szita, sp. n.}

http://zoobank.org/AFE6A314-D608-4728-B3CD-BB3E2BFDF8EE

Figs 1, 5a, 6a-b

Material. Type material: Holotype female Switzerland, Valais, s/Venayaz, $700 \mathrm{~m}$ a.s.l., 7.x.1980, leg. C. Besuchet [PPI 8864, MHNG without code]. Paratypes female: 6 adult females with the same data as holotype, on separate slides.

Other material examined: 3 adult females on separate slides, Switzerland, Valais, Dorenaz, oak, 28.iii.1964, leg. C. Besuchet [PPI 8862, MHNG without code].

Description. Live adult female: dorsum with 9 pairs dorsal wax plates in each marginal row, 8 pairs in each submedian band, and 3 triangular or shield-shaped plates in middle of thorax. Ovisac short, about half length of body (Fig. 5a).

Slide-mounted adult female (Figs 1, 6a-b). Body elongate oval, 2.124-2.719 mm long, 1.425-1.942 mm wide. Antenna 7 segmented. Measurements of antennal segments: $1^{\text {st }} 180-230,2^{\text {nd }} 183-209,3^{\text {rd }} 96-117,4^{\text {th }} 84-107,5^{\text {th }} 76-92,6^{\text {th }} 76-96$ and apical 204-220 mm long, apical spine of antenna 22-24 mm long, subapical seta absent; fleshy sensory seta near apical seta 22-24 mm long; all segments of antenna covered with very robust, spine-like setae, the longest $17 \mathrm{~mm}$ long; first antennal segment with 4 spines on each side of segment. Eyes sub-conical, well separated from base of first antennal segment.

Venter: Labium 260-285 mm long, apparently one segmented. Stylet loop usually longer than labium. Legs well developed; leg measurements: front coxa 155-189 mm, middle 155-189 mm, hind 188-204 mm; front trochanter+femur 546-577 mm long, middle 548-572 mm, hind 597-650 mm; front tibia+tarsus 700-722 $\mathrm{mm}$ long, middle 679-740 $\mathrm{mm}$, hind 804-866 $\mathrm{mm}$; claw 74-89 $\mathrm{mm}$ long; hind claw digitules 


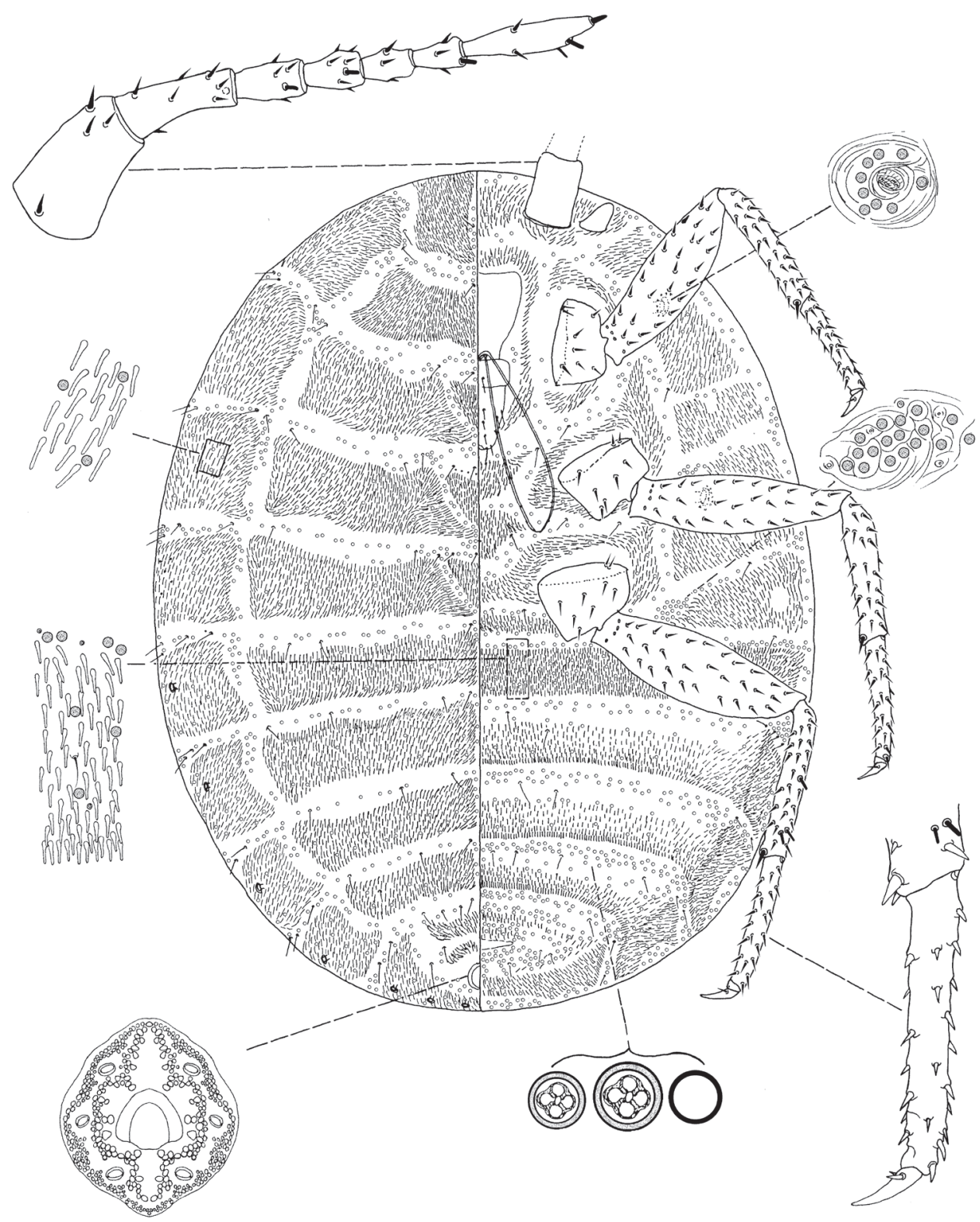

Figure I. Arctorthezia helvetica sp. n., mounted adult female. Illustration by Konczné Benedicty \& Kaydan.

each 15-21 mm. Legs with rows of robust spine-like setae, tibia with fleshy sensory seta $24 \mathrm{~mm}$ long, trochanter with 4 placoid sensilla on each surface. Wax plates present on ventral areas of head and thorax, with wide marginal plate laterad of each thoracic spiracle; two wax plates present between mid-coxae, both triangular, almost same size (Fig. 6a). 
Thoracic spiracle with wide band of disc pores inside atrium. Setae few, scattered in medial areas of thorax; several setae near anterior edge of ovisac band and associated with simple pores. Ovisac band wide, parallel side in the middle, with 4 spine rows within ovisac band. Multilocular pores with 4 loculi around perimeter, each loculus $4-5 \mathrm{~mm}$ in diameter and 1 loculus in central hub, $3 \mathrm{~mm}$ in diameter; pores present in 3 complete bands near posterior edges of each spine band, and scattered around vulva.

Dorsum: Wax plates covering entire dorsum; three triangular wax plates on middorsum, anteriormost 185-190 mm wide, 135-150 mm long; middle 250-270 mm wide, 150-160 mm long; posteriormost 260-280 mm wide, 170-180 mm long (Fig. $6 \mathrm{~b})$. Spines at margin of each wax plate each $22-24 \mathrm{~mm}$ long, apically capitate. A few setae present in marginal clusters near posterior edges of marginal wax plates; $3-6$ setae present laterad of thoracic spiracle, longest seta $24 \mathrm{~mm}$ long; also present in very small numbers on other wax plates and in medial bare area. Multilocular pores generally with 4 loculi around perimeter and one loculus in central hub, sparsely present in wax plates. Abdominal spiracles numbering 8 pairs on the margin, last 3 pairs situated in posterior apical spine clusters. Anal ring 108-120 mm long, 108-120 wide, bearing 6 blunt anal ring setae, each 156-192 mm long.

Etymology. he species was named after the ancient name of its locus typicus, Switzerland (Helvetia).

Distribution. Switzerland.

Ecology. Host plant: unknown, found in leaf litter and soil samples.

Diagnosis. Arctorthezia helvetica sp. n. can be recognized by the following combination of characters: (i) 7-segmented antennae, (ii) dorsal triangle-shaped midthoracic setal plates hardly wider than long (iii) the proportion of simple pores and quadrilocular pores distal to vulva ca. 1:15, (iv) diamond-shape setal plate between mid-coxae on venter.

Comments. Arctorthezia helvetica sp. n. is closest to A. occidentalis in having 4 spine rows within the ovisac band and lacking circular pore clusters on the dorsum, but differs from $A$. occidentalis as follows (characters of $A$. occidentalis in brackets): (i) adult female body length less than $3 \mathrm{~mm}$ (adult female body length at least $3.5 \mathrm{~mm}$ ); (ii) the fourth spine row within ovisac band weak (the fourth spine row within ovisac band strong); (iii) the proportion of simple pores to quadrilocular pores distal to vulva ca. 1:15 (the proportion of simple pores to quadrilocular pores distal to vulva ca. 1:6); (iv) dorsal triangle-shaped mid-thoracic setal plates hardly wider than long (dorsal triangleshaped mid-thoracic setal plates more than two times wider than long).

\section{Arctorthezia cataphracta (Olafsen, 1772)}

Figs 2, 5b-c, 6c-d

Material examined. Austria: 1 female, Kesselspitze Mt., 3.vii.1999, leg. K. Thaler [PPI 6545]. Greenland: 2 females on 1 slide, s-o, Nanortalik, dwarf willow, 26.vii.1979, leg. G. Primatesta [PPI 8933, MHNG nr.7]; 1 female at Boston, Sedum sp., 6.vi.1945, leg. 


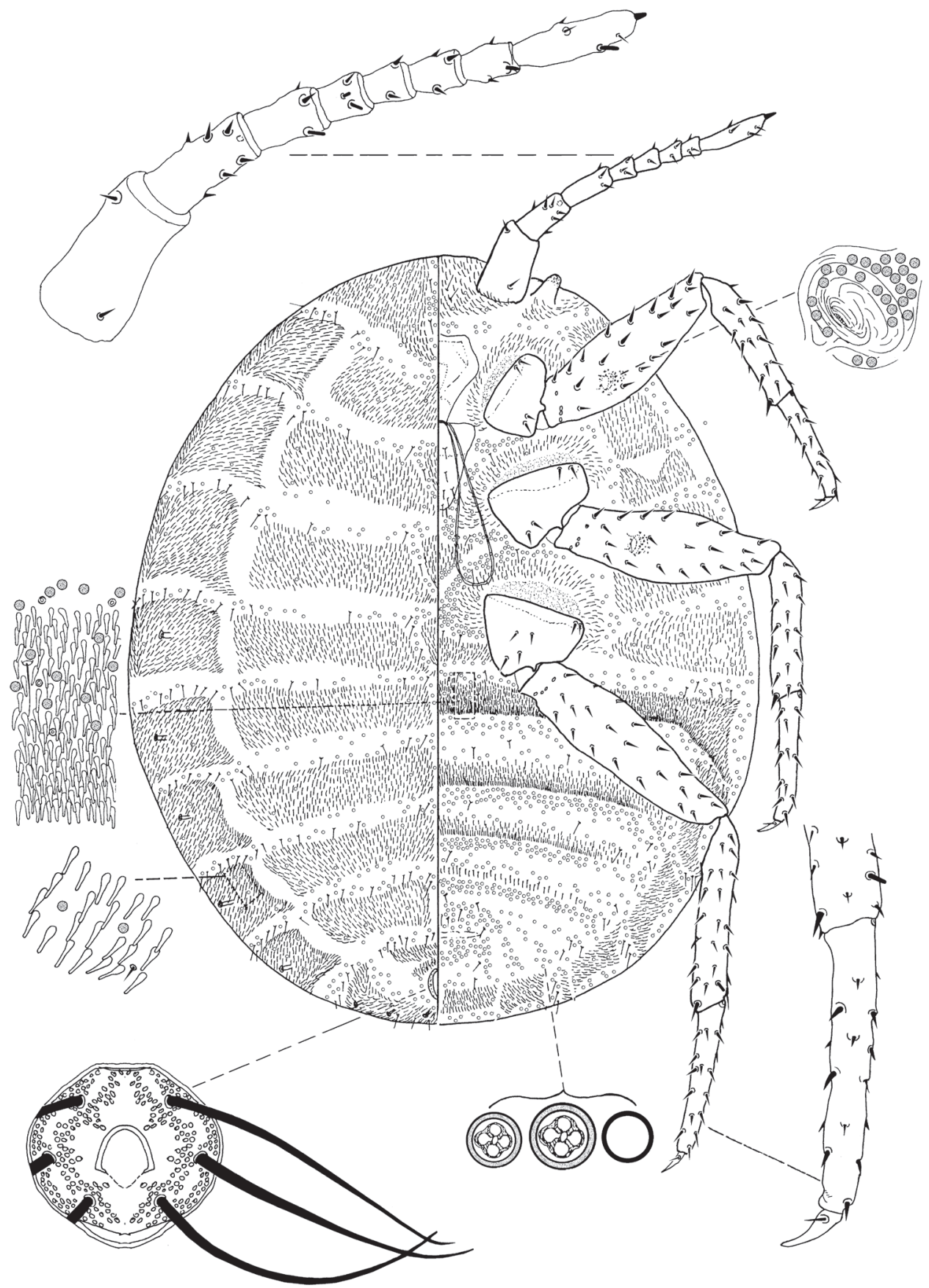

Figure 2. Arctorthezia cataphracta (Olafsen, 1772), mounted adult female. Illustration by Konczné Benedicty \& Kaydan. 
Hodson [PPI 8967, USNM 45 1781]. Italy: 2 females on 2 slides, Piedmont, Monte Autoroto, 1700 m a.s.l., 16.vi.1982, leg. A. Focarile [PPI 9854, MHNG 13]. Japan: 1 female, Tochigi, Nikkô, Kawamata, Nikkô-zawa-onsen, 1500 m a.s.l., Dryopteris crassirhizoma, 5.vi.2013., leg. S. Maehara. (collected by beating) [TRPM]; 1 female, same locality, Dryopteris crassirhizoma, 2.vii.2013, leg. S. Maehara. (collected by beating) [TRPM]. Mongolia: 1 female, Bogdo, 3.vi.1967, leg. Z. Kaszab [HNHM As 77]. Switzerland: 2 females on 2 slides, Valais, Gornergat, $3050 \mathrm{~m}$ a.s.l., under stones, 12.ix.1982, leg. C. Besuchet [PPI 8857, MHNG without code]; 3 females on 3 slides, Valais, Fluhalp, near Leuerbad, $2000 \mathrm{~m}$ a.s.l., mosses and dead leaves, 14.viii.1980, leg. C. Besuchet [PPI 8858, MHNG without code]; 2 females on 2 slides, Obwald, Melchsee, 1800 m a.s.l., mosses, 2.x.1987, leg. I. Löbl [PPI 8861, MHNG without code]; 4 females on 4 slides, Valais, Tursten, s/Zermatt, 2200 m a.s.l., 14.vii.1966, leg. A. Comellini [PPI 8863]; 5 females on 5 slides, Valais, Saas-Almagell, $1650 \mathrm{~m}$ a.s.l., wet mosses, 5.vii.1997, leg. C. Besuchet [PPI 8866, MHNG without code]; 2 females on 2 slides, Valais, Grand St. Bernard, 2150 m a.s.l., mosses at foot of rocks, 10.ix.1996, leg. C. Besuchet [PPI 8873, MHNG without code]; 1 female, at N.Y., on lichens around Rhododendron, 12.vii.1938, leg. Harley [PPI 8968, USNM 98-2244, NY77615]; 1 female, Valais, Torrenthorn, near Lukerbad, 2500-2600 m a.s.l., alpine meadows, 12.viii.1980, leg. C. Besuchet [PPI 8870, MHNG without code]; 1 female, Studen, moss, 20.ix.1992, leg. F. Kozár [PPI 4071]; 1 female, Romoos, Weise, 23.viii.1994, leg. Rézbányai [PPI 6144, HNHM]; 2 females on 1 slide, Romoos, Weise, 28.iv.1994, leg. Rézbányai [PPI 6143]. Turkey: 1 female, Ilgardagi Gecidi, 2350 m a.s.l., 13.vi.1986, leg. Löbl, Besuchet, Burckhardt [PPI 8881, MHNG without code]; 2 females on 2 slides, Kars, Ilgandas, Gecidi, on herbs and flowers, 13.vi.1986, leg. Löebl \& Bernhardt [MHNG 10699/1-2 Ar.tube II]. UK: 2 females on 1 slide, Scotland, N. Berwich, E. Lothian, under moss, .ix.1926, leg. E.E. Green [PPI 8965, USNM without code]; 1 female, Scotland, Braemar, at base of grass, 8.viii.1979, leg. J.N. Cox [USNM 5/79].

Synonymy. Pediculus cataphractus Olafsen, Coccus cataphracta (Shaw), Dorthezia cataphracta (Shaw), Orthezia cataphracta (Shaw), Dorthesia chiton Zetterstedt, Orthezia signoreti White, Coccus uva (Modeer), Orthezia uva (Modeer), Orthezia (Arctorthezia) cataphracta, Cockerell, Coccus cataphractus Lindinger (Ben-Dov et al. 2014, Kozar 2004).

Description. Live adult female: dorsum with 9 pairs dorsal wax plates in each marginal row, 8 pairs in each submedian band, and 3 small triangular or shield-shaped ones in middle of thorax. Ovisac parallel sided, short, about half length of body (Fig. 5b-c).

Slide-mounted adult female (Figs 2, 6c-d). Body elongate oval, 2.0-2.9 mm long, 1.5-2.7 mm wide. Antenna 8 - (rarely 6 or 7) segmented. Measurements of antennal segments: $1^{\text {st }} 189-273,2^{\text {nd }} 144-210,3^{\text {rd }} 102-145,4^{\text {th }} 64-110,5^{\text {th }} 61-93,6^{\text {th }} 67-90$, $7^{\text {th }} 70-115$, and apical segment $176-220 \mathrm{~mm}$ long, apical spine of antenna $11-20$ $\mathrm{mm}$ long, subapical seta absent; fleshy sensory seta near apical seta $13-21 \mathrm{~mm}$ long; all segments of antenna covered with very robust, spine-like setae, the longest spine 21-37 mm long; first antennal segment with 0-2 spines on each side of segment. Eyes conical, well separated from base of first antennal segment. 
Venter: Labium 285-350 mm long, apparently one segmented. Stylet loop usually longer than labium. Legs well developed; leg measurements: coxa length: front 186-310 $\mathrm{mm}$ long, middle 192-300 mm, hind 224-330 mm; front trochanter+femur 623-800 $\mathrm{mm}$ long, middle $647-820 \mathrm{~mm}$, hind $705-883 \mathrm{~mm}$; front tibia+tarsus $423-991 \mathrm{~mm}$ long, middle 448-994 mm, hind 548-1165 mm; front claw 82-106 mm long, middle 96-108 mm, hind 97-120 mm; hind claw digitules each 26-39 mm. Legs each with rows of robust spine-like setae, with a fleshy sensory seta on hind tibia, trochanter with 4 placoid sensilla on each surface. Wax plates present on ventral areas of head and thorax, and wide marginal plate laterad of each thoracic spiracle; two wax plates present between mid-coxae, both in triangular shape, anterior one relatively small and longer than wide (Fig. 6c); with 3 spine rows within ovisac band. Thoracic spiracles each with wide band of disc pores inside atrium. Setae few, scattered in medial areas of thorax, with several setae near anterior edge of ovisac band and associated with simple pores. Ovisac band narrow, indented in the middle. Multilocular pores each with 4 loculi around perimeter and 1 loculus in central hub, $4-5 \mathrm{~mm}$ in diameter; present in 3 complete bands near posterior edge of each spine band, and scattered around vulva.

Dorsum: Wax plates cover entire dorsum; three triangular wax plates on mid-dorsum, anterior 40-130 mm wide, 60-195 mm long; middle 60-120 mm wide, 90-250 $\mathrm{mm}$ long; posterior 80-110 mm wide, $90-240 \mathrm{~mm}$ long, (Fig. 6d). Spines at margin of wax plate each $14-20 \mathrm{~mm}$ long, apically capitate. A few setae present in marginal clusters near posterior edges of marginal wax plates; with 3-6 setae laterad of thoracic spiracles, longest seta $17-20 \mathrm{~mm}$ long; also present in very small numbers on other wax plates and in medial bare area. Multilocular pores generally each with 4 loculi around perimeter, one loculus in central hub, sparsely present in wax plates. Abdominal spiracles numbering 8 pairs on the margin, last 3 situated in posterior apical spine clusters. Anal ring 120-132 mm long and 118-146 wide, bearing 6 blunt anal ring setae, each seta $136 \mathrm{~mm}$ long.

Distribution. Austria, Belgium, Canada, Czech Republic, Denmark (Faeroe Islands), Estonia, Finland, France, Georgia, Greece, Greenland, Iceland, Ireland, Italy, Japan, Mongolia, Norway, Poland, Romania, former Soviet Union, Spain, Sweden, Switzerland, U.K., Ukraine, U.S.A. (Alaska).

Ecology. Host plants: Alnus viridis (Betulaceae), Caltha sp. (Ranunculaceae), Capparis sp. (Capparaceae), Calamagrostis langsdorfi, Carex sp., Deschampsia caespitosa (Poaceae), Chrysanthemum alpinum, Hieracium sp., Hymogyne sp., Solidago sp. (Asteraceae), Dryas octopetala (Rosaceae), Gentiana sp. (Gentianaceae), Geranium sp. (Geraniaceae), Iris setose (Iridaceae), Racomitrium lanuginosum (Grimmiaceae), Calluna vulgaris, Rhododendron ferrugineum, Vaccinium myrtillus (Ericaceae), Saxifraga aizoon (Saxifragaceae), S. cuneifolia, S. oppositifolia, Sedum sp. (Crassulaceae), Soldanella sp. (Primulaceae), Trientalis europaea (Myrsinaceae), and Collybia sp. (Fungi: Tricholomataceae). Under mosses (Sphagnum sp.: Sphagnaceae) and stones on roots, also reported from ant nests (Ben-Dov et al. 2014, Kozár 2004). In Primorsky region of Russia (Danzig 1980) and Japan, some individuals were observed on ferns. 


\section{Arctorthezia occidentalis (Douglas, 1891)}

Figs 3, 5d-e, 6e-f

Material examined. Canada: 2 females on 1 slide, British Columbia, Victoria, Highland Rd., moss, 12.vii.1988, leg. F. Kozár [PPI 3330, USNM 57]; 2 females on 1 slide, British Columbia, Vancouver Island, Ladysmith, entering a dwelling, 9.xi.1945, leg. W.A. Ross [PPI 8986, USNM 45-2340]; 6 females on 4 slides, British Columbia, Kaslo B.C., root of trees and grass, 19.v.1908, leg. J.W. Cockle [PPI 8974, USNM without code]; USA: 5 females on 5 slides, Montana, on apple, .ix.1949, leg. W.S. Regan [PPI 8975, USNM 49-2173]; 1 female, Colorado, Boulder, on Castilleja sp., 8.vi.1917, leg. H.F. Dietz [PPI 8977, USNM FHB \#16096]; 4 females on 2 slides, Colorado, Boulder, on Castilleja sp., 12.vi.1919, leg. H.F. Dietz [PPI 8976, USNM without code].

Synonymy. Orthezia occidentalis Douglas, Orthezia californica (Ehrhorn), Orthezia (Arctorthezia) occidentalis Morrison (Ben-Dov et al. 2014).

Description. Adult female, with secretion, fairly large, $3.5 \mathrm{~mm}$ wide and $4.5 \mathrm{~mm}$ long. Body completely covered with dense, sharply defined wax plates, these occurring in the usual marginal and dorsal tufts, white or variously discoloured, sometimes appearing yellow-brown or grey (Morrison 1925). Live adult female with 9 paired dorsal wax plates in each marginal row, 8 in each submedian band, and 3 wide, triangular or shield-shaped plates in centre of thorax (Fig. $5 \mathrm{~d}-\mathrm{e}$ ).

Slide-mounted adult female (Fig. 3, 6e-f). Body elongate oval, 3.45-4.25 mm long, 3.00-2.68 mm wide. Antenna 8- (rarely 7) segmented. Measurements of antennal segments: $1^{\text {st }} 280-330,2^{\text {nd }} 190-230,3^{\text {rd }} 110-140,4^{\text {th }} 100-110,5^{\text {th }} 90,6^{\text {th }} 90-100,7^{\text {th }}$ 90-120, and apical segment 235-240 mm long; apical spine of antenna $20 \mathrm{~mm}$ long, subapical seta absent; fleshy sensory seta near apical seta $25 \mathrm{~mm}$ long, all segments of antennae covered with very robust, spine-like setae, longest spine $15 \mathrm{~mm}$ long, first antennal segment with 2 spines on each side of segment. Eye with sub-parallel sides, tall, 120-180 mm long, situated very close to first segment of antenna.

Venter: Labium 340-450 mm long, apparently one segmented. Stylet loop usually longer than labium. Legs well developed; measurements of front coxa 220-260 mm long, middle 200-250 mm, hind 240-350 mm; front trochanter+femur 660-720 mm long, middle $720-820 \mathrm{~mm}$, hind $760-920 \mathrm{~mm}$; front tibia+tarsus $460-670 \mathrm{~mm}$ long, middle 540-580 mm, hind 340-400 mm; front claw $80 \mathrm{~mm}$ long, middle 90-110 $\mathrm{mm}$, hind 90-110 $\mathrm{mm}$; hind claw digitules 5-10 $\mathrm{mm}$; legs with rows of robust spinelike setae, with four fleshy sensory setae on tibia, trochanter with 4 placoid sensilla on each surface. Wax plates present on ventral areas of head and thorax, with wide marginal plate laterad of each thoracic spiracle; two wax plates present between mid-coxa upper one in triangular shape (Fig. 6e), below one knickers shape. Thoracic spiracles with wide band of disc pores inside atrium. Setae few, scattered in medial areas of thorax, with several setae near anterior edge of ovisac band and associated with simple pores. Ovisac band wide, straight in the middle; with 4 spine rows within ovisac band. Multilocular pores with 4 loculi around perimeter, 1 loculus in central hub; $5 \mathrm{~mm}$ in 


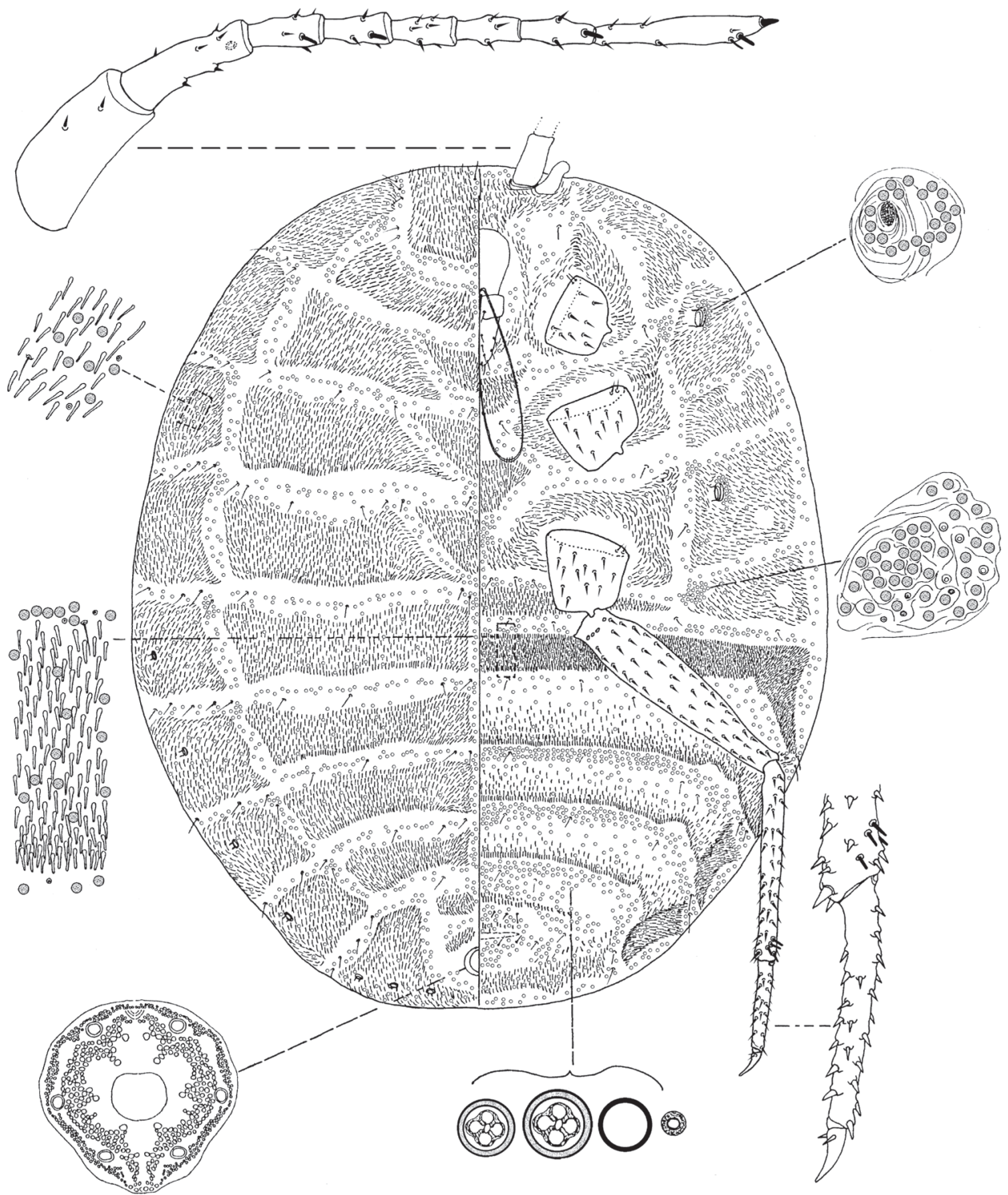

Figure 3. Arctorthezia occidentalis (Douglas, 1891), mounted adult female. Illustration by Konczné Benedicty \& Kaydan.

diameter; present in 3 complete bands near posterior edges of each spine bands, and scattered around vulva.

Dorsum: Wax plates cover all dorsum; three triangular wax plates on middorsum (first 340-540 $\mathrm{mm}$ in width, $140-240 \mathrm{~mm}$ in length; middle $440-740 \mathrm{~mm}$ in width, $300-370 \mathrm{~mm}$ in length; third $640-650 \mathrm{~mm}$ in width, $220-330 \mathrm{~mm}$ in length, Fig. $6 \mathrm{f})$. Spines at margin of wax plate $20-22 \mathrm{~mm}$ long, spines apically capitate. A few setae 
present in marginal clusters near posterior edges of marginal wax plates, with 3-6 setae laterad of thoracic spiracles, longest seta 40-50 $\mathrm{mm}$ long also present in very small numbers on other wax plates and in medial bare area. Multilocular pores generally with 4 loculi around perimeter, one loculus in central hub, sparsely present in wax plates. Abdominal spiracles 7 pairs on the margin, last 2 in posterior apical spine clusters. Anal ring 130-145 mm long and 100-125 wide with 6 anal ring blunted setae, each 225-250 mm long.

Distribution. Canada (British Columbia), Spain, USA (Alaska, California, Colorado, Hawaiian Islands, Idaho, Montana, New Mexico, Oregon, Washington).

Ecology. Host plant: Bahia sp., Eriophyllum, Argyroxiphium sp., Eriophyllum confertifolium, Agrostis sandwicensis, Grossularia sp., Fragraria sp. Rubus sp., Castilleja sp (Ben-Dov et al. 2014, Kozar 2004).

Biology. On the roots, associated with Formica integra, and Myrmica? ants (BenDov et al. 2014, Kozar 2004).

Comments. Its presence in the Palaearctic Region (Spain) (Gómez-Menor 1937) is under question. Searches for slides in Spanish collections were unsuccessful (personal communication from Carolina Martin (Madrid), and Angeles Vásquez (Madrid)).

\section{Arctorthezia pseudoccidentalis Morrison, 1952}

Figs 4, 5f-g, 6g-h

Material examined. USA: 4 females on 4 slides, Nevada, $15 \mathrm{mi}$ S of Ely, beneath boards, 6.vii.1960, leg. T.R. Haig [PPI 8964, USNM 60-0381]

Description. Adult female, with secretion, fairly large, similar to $A$. occidentalis. Body completely covered with dense, sharply defined wax plates, these occurring in the usual marginal and dorsal tufts, white. With 3 wide, shield-shaped plates in centre of thorax (Fig. 5f-g).

Slide-mounted adult female (Fig. 4, 6g-h). Body elongate oval, $4.015 \mathrm{~mm}$ long, $3.497 \mathrm{~mm}$ wide. Antenna 7 or 8 segmented. Measurements of antennal segments: $1^{\text {st }}$ $320-350,2^{\text {nd }} 227-260,3^{\text {rd }} 144-155,4^{\text {th }} 113-124,5^{\text {th }} 103,6^{\text {th }} 93-103,7^{\text {th }} 103$, apical segment $191 \mathrm{~mm}$ long; apical spine of antenna $26 \mathrm{~mm}$ long, subapical seta absent; fleshy sensory seta near apical seta $18 \mathrm{~mm}$ long; all segments of antennae covered with very robust, spine-like setae, longest spine $11 \mathrm{~mm}$ long; first antennal segment with 2 spines on each side of segment. Eye with sub-parallel sides, tall, situated very close to first segment of antenna.

Venter: Labium 391-402 mm long, apparently one segmented. Stylet loop usually longer than labium. Legs well developed; measurements of front coxa 247-310 mm long, middle 309-330 mm, hind 330-340 mm; front trochanter+femur $917 \mathrm{~mm}$ long, middle $958 \mathrm{~mm}$, hind 1060-1088 mm; front tibia+tarsus not seen, middle 649 $\mathrm{mm}$, hind 824-868 mm; front claw 1 not seen, middle $108 \mathrm{~mm}$, hind $113 \mathrm{~mm}$; hind claw digitules 23-26 mm; legs with rows of robust spine-like setae, without 2 fleshy sensory seta on tibia each $10 \mathrm{~mm}$, trochanter with 4 placoid sensilla on each surface. 


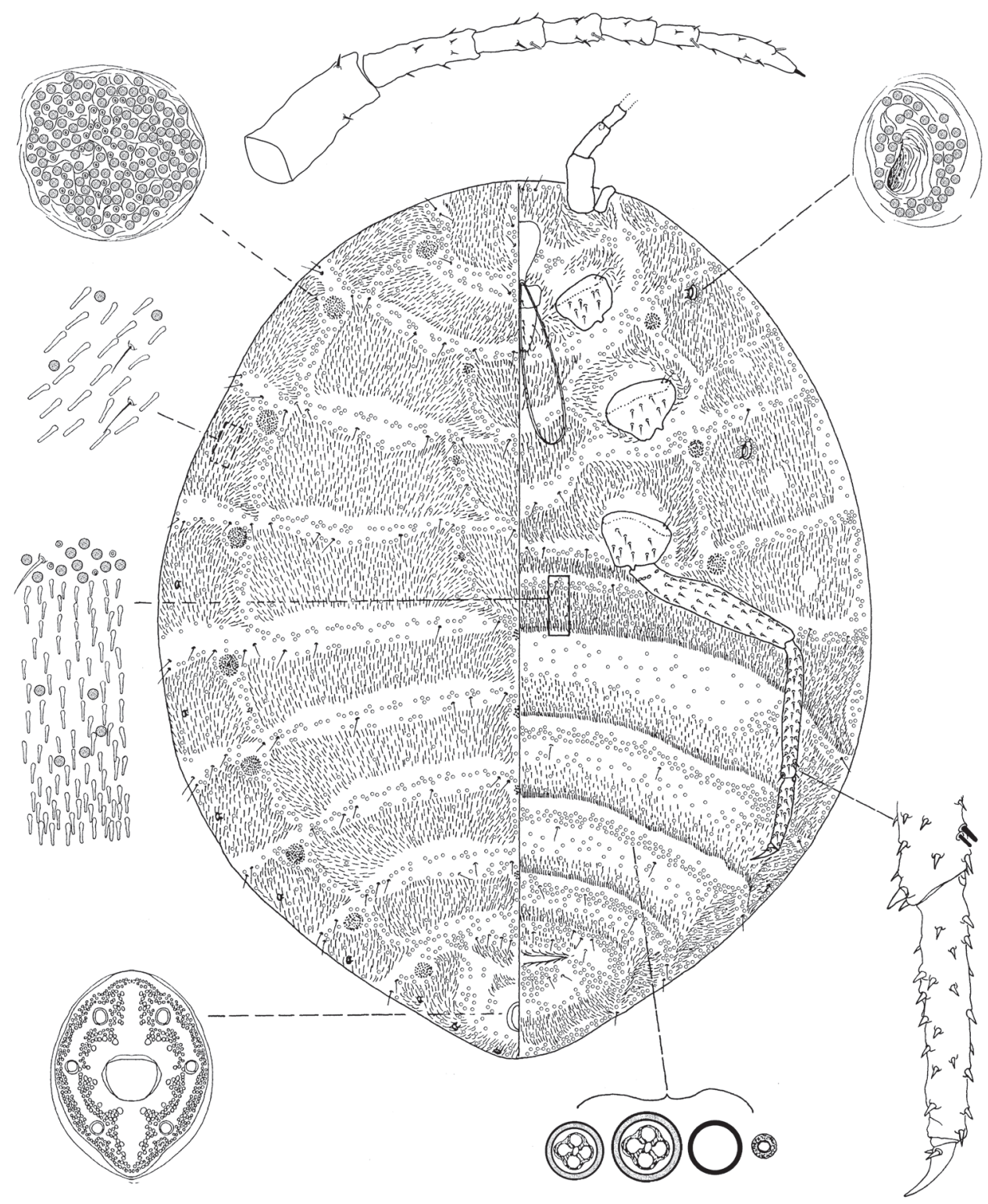

Figure 4. Arctorthezia pseudoccidentalis Morrison, 1952, mounted adult female. Illustration by Konczné Benedicty \& Kaydan.

Wax plates present on ventral areas of head and thorax, with wide marginal plate laterad of each thoracic spiracle; two wax plates present between mid-coxa in wide triangular shape, below one wide arch shape, with 4 spine rows within ovisac band (Fig. $6 \mathrm{~g})$. Thoracic spiracles with wide band of disc pores inside atrium. Setae few, scattered in medial areas of thorax, with several setae near anterior edge of ovisac band and associated with simple pores. Ovisac band wide. With four wide wax plate bands within 


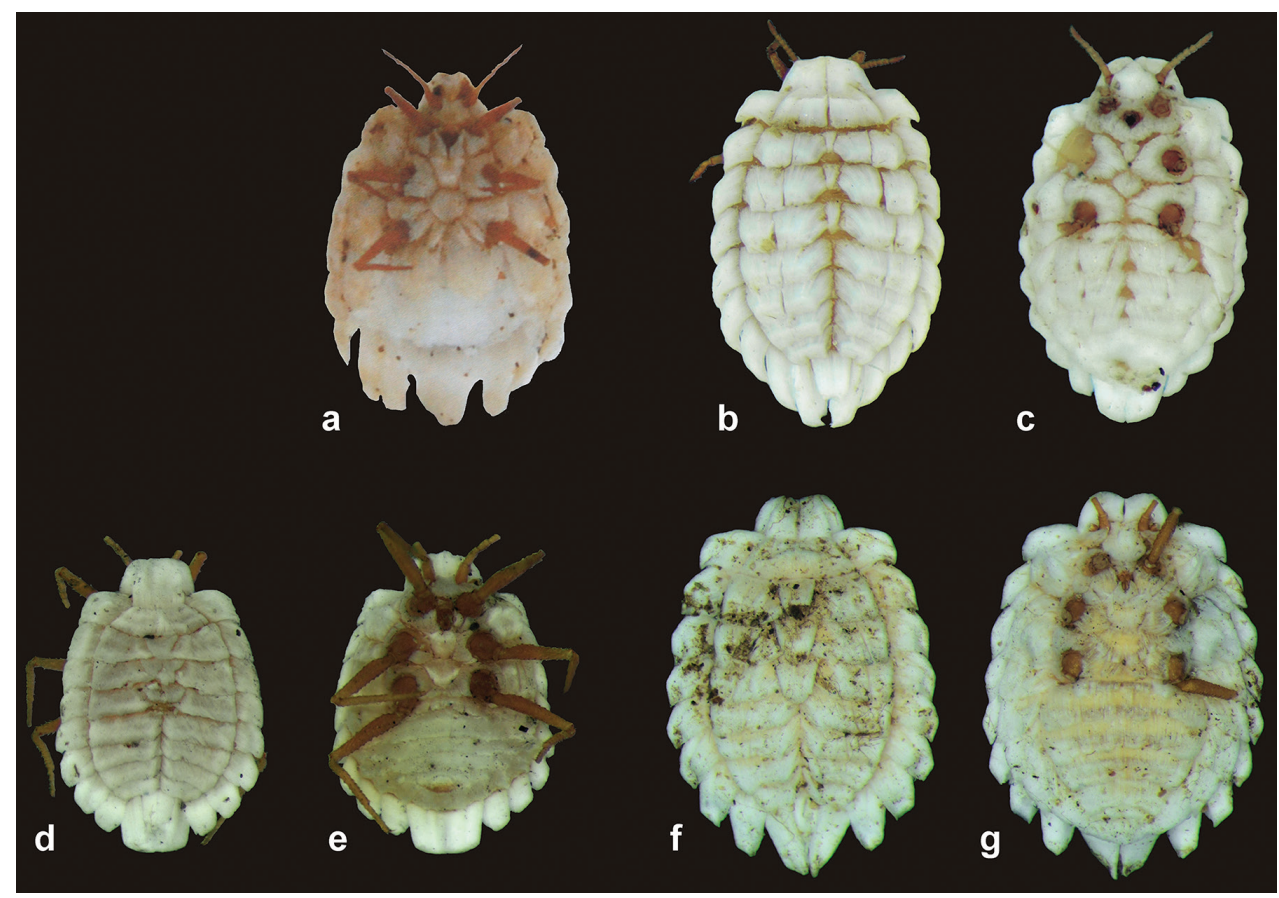

Figure 5. Dorsal and ventral views of unmounted adult female Arctorthezia species. A. helvetica sp. n., a venter. A. cataphracta $\mathbf{b}$ dorsum $\mathbf{c}$ venter. A. occidentalis $\mathbf{d}$ dorsum e venter. A. pseudoccidentalis $\mathbf{f}$ dorsum $\mathbf{g}$ venter. Photographs by: a P. van Helsdingen b-g É. Szita.

ovisac band. Multilocular pores with 4loculi around perimeter, 1 loculus in central hub; $5 \mathrm{~mm}$ in diameter; present in 4 complete bands near posterior edges of each spine bands, and scattered around vulva.

Dorsum: Wax plates cover all dorsum; three shield-shaped setae plates on middorsum (first 390-540 mm in width, $290-400 \mathrm{~mm}$ in length; middle $540-710 \mathrm{~mm}$ in width, 330-460 $\mathrm{mm}$ in length; third $570-720 \mathrm{~mm}$ in width, $370-460 \mathrm{~mm}$ in length, Fig. 6h), 9 circular pores clusters, separating the dorsal and marginal wax plate bands. Spines at margin of wax plate 22-27 mm long, spines apically capitate. A few setae present in marginal clusters near posterior edges of marginal wax plates, with 3-6 setae laterad of thoracic spiracles, longest seta $40-50 \mathrm{~mm}$ long also present in very small numbers on other wax plates and in medial bare area. Multilocular pores generally with 4 loculi around perimeter, one loculus in central hub, sparsely present in wax plates. Abdominal spiracles 8 pairs on the margin, last 3 in posterior apical spine clusters. Anal ring $161 \mathrm{~mm}$ long and 127-138 wide with 6 anal ring blunted setae, each 259-264 mm long.

Distribution. USA (California, Idaho, Nevada, Washington).

Ecology. Host plant: Berberis aquifolium (Berberidaceae). Grass roots, litter under different trees, often under rocks.

Concluding comment. Macromorphological characters of ortheziid species, such as the shape, number and arrangement of the wax plates of live (or dead) ensign scales 

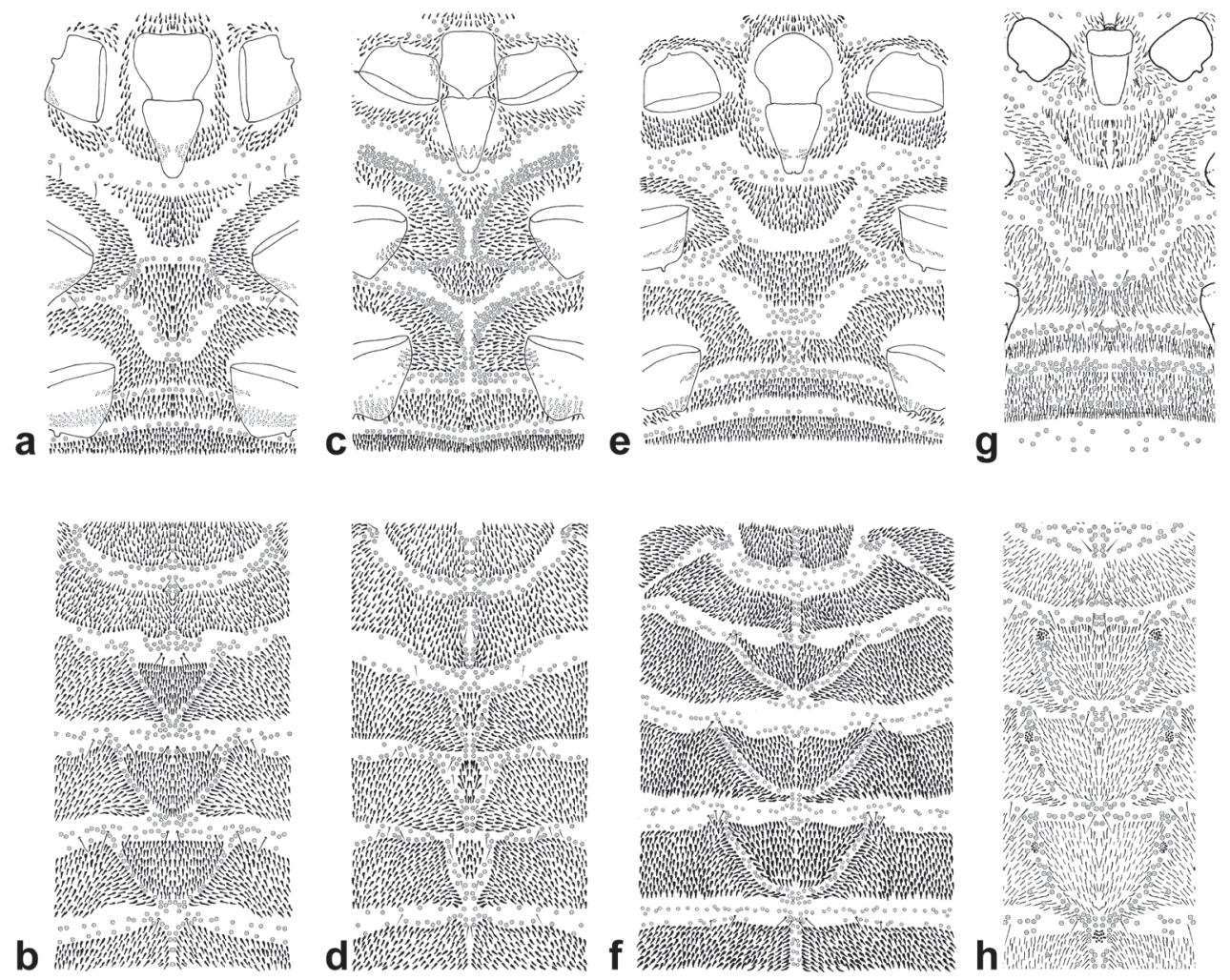

Figure 6. Enlargement of mid-dorsal and mid-ventral thoracic region of Arctorthezia species. A. helvetica sp. n., a ventral b dorsal; $A$. cataphracta $\mathbf{c}$ ventral $\mathbf{d}$ dorsal; $A$. occidentalis e ventral $\mathbf{f}$ dorsal; $A$. pseudoccidentalis $\mathbf{g}$ ventral $\mathbf{h}$ dorsal. Illustrations by Konczné Benedicty \& Kaydan.

have been useful for genus and in some cases for species identification (Kondo et al. 2013, Kozár 2004, Szita et al. 2010). These wax plates on the intact body (Fig. 5) do not always have the same appearance as the wax plates of the mounted female (Figs $1-4,6)$. For example, the submedial dorsal wax plates of $A$. cataphracta are apparently in two parts on the intact body (Fig 5b), while on the mounted female there is only one undivided wax plate on each tergite in the same position (Fig. 2). In the case of Arctorthezia species both the usability and limitations of this method for separating species within the genus are clear; the medial wax plates and midcoxal wax plates can be useful characters for quick separation of species (Figs 5-6). Nevertheless, the correct identification of a species needs always to be confirmed by slide mounting.

\section{Acknowledgements}

We would like to thank the OTKA (Hungarian National Science Found) (Grant No. $\mathrm{T}$ 048801, T 075889) for funding this project. The second author (MBK) thanks 
TUBITAK for their financial support to enable study of the family Ortheziidae in Hungary. The authors wish to thank Dr. Peter Schwendinger, the curator of Arachnida Collection of Muséum d'Histoire naturelle de Genève, Switzerland; Dr. Douglas J. Williams at the Natural History Museum, London, U.K.; and Dr Douglass Miller at Systematic Entomology Laboratory of USDA, Beltsville, Maryland, U.S.A., for their kind help and for making it possible for us to study those collections. We wish to thank to Dr. Peter Schwendinger for macrophotography of the new species. Special thanks go to Dr. Gillian W. Watson (California Department of Agriculture, Sacramento, California, U.S.A.) for reviewing the manuscript. We are grateful for the useful comments of two referees of the manuscript, Prof. Giuseppina Pellizzari and Dr Yair Ben-Dov.

\section{References}

Ben-Dov Y, Miller DR, Gibson DAP (2014) Scalenet. http://www.sel.barc.usda.gov/scalenet/ scalenet.htm [accessed on 12 Aug 2013]

Cockerell TDA (1902) The nomenclature of the Coccidae. The Entomologist 35: 114.

Danzig EM (1980) [Coccoids of the Far East USSR (Homoptera, Coccinea) with phylogenetic analysis of scale insects fauna of the world.] Nauka, Leningrad, 367 pp. [In Russian]

Hadley A (2010) Combine ZP Software. http://www.hadleyweb.pwp.blueyonder.co.uk/CZP/ News.htm

Hadzibejli ZK (1963) [Coccids of the family Ortheziidae (Homoptera, Coccoidea) in the fauna of Georgia.] Entomologicheskoe Obozrenye 42: 611-620. [In Russian]

International Commettee of Zoological Nomenclature (1999) International Code of Zoological Nomenclature, $4^{\text {th }}$ edition. International Trust for Zoological Nomenclature, London. http:// iczn.org/iczn/index.jsp

Kosztarab M, Kozár F (1988) Scale Insects of Central Europe. Akadémiai Kiadó, Budapest, $456 \mathrm{pp}$.

Koteja J (1996) Scale insects (Homoptera: Coccinea) a day after. In: Schaefer CW, Say T (Eds) Publications in Entomology. Proceedings. Studies on Hemipteran Phylogeny. Entomological Society of America, Lanham, MD, 65-88.

Kondo T, Peronti AL, Kozár F, Szita É (2013) The citrus orthezia, Praelongorthezia praelonga (Douglas) (Hemiptera: Ortheziidae), a potential invasive species. In: Pena JE (Ed) Potential Invasive Pests of Agrigultural Crops. CAB International, Wallingford, 301-319. doi: $10.1079 / 9781845938291.0301$

Koteja J, Zak-Ogaza B (1988) Arctorthezia antiqua sp. n. (Homoptera, Coccinea) from Baltic amber. Annales Zoologici Polska Akademia Nauk, Instytut Zoologiczny 41: 1-8.

Kozár F (2004) Ortheziidae of the World. Plant Protection Institute, Hungarian Academy of Sciences, Budapest, Hungary, 525 pp.

Morrison H (1925) Classification of scale insects of the subfamily Ortheziinae. Journal of Agricultural Research 30: 97-154.

Richard C (1998) Ortheziidae. In: Kozár F (Ed.) Catalogue of Palaearctic Coccoidea. Plant Protection Institute, Hungarian Academy of Sciences, Budapest, 444-450. 
Szita É, Kozár F, Konczné Benedicty Z (2010) Study of some new macromorphological characters in Ortheziidae (Hemiptera, Coccoidea). Poster and Abstract. In: XII. International Symposium on Scale Insct Studies, 06-09 April 2010, Chania, Crete, Hellas.

Vea I, Grimaldi DA (2012) Phylogeny of ensign scale insects (Hemiptera:Coccoidea: Ortheziidae) based on the morphology of Recent and Fossil Females. Systematic Entomology 37: 758-783. doi: 10.1111/j.1365-3113.2012.00638.x 